\title{
Model-based analysis of the energy fluxes and trophic structure of a Portunus trituberculatus polyculture ecosystem
}

\author{
Jie Feng ${ }^{1}$, Xiang-Li Tian ${ }^{1, *}$, Shuang-Lin Dong ${ }^{1}$, Rui-Peng He ${ }^{1}$, Kai Zhang ${ }^{1}$, \\ Dong-Xu Zhang ${ }^{1}$, Qing-Qi Zhang ${ }^{2}$
}

\author{
${ }^{1}$ The Key Laboratory of Mariculture, Ministry of Education, Fisheries College, Ocean University of China, Qingdao 266003, \\ PR China \\ ${ }^{2}$ Marine Fishery Technology Guiding Office of Ganyu, Lianyungang 222100, PR China
}

\begin{abstract}
We constructed a quantitative Ecopath model of a trophic network to evaluate the energy flow and properties in a polyculture ecosystem containing 4 species (swimming crab Portunus trituberculatus, white shrimp Litopenaeus vannamei, short-necked clam Ruditapes philippinarum, and redlip mullet Liza haematochila) over a $90 \mathrm{~d}$ experimental period. The model contained 10 consumers, 4 detritus groups, and 4 primary producers. Ecotrophic efficiency values indicated that the system had high energy utilization efficiency. However, benthic bacteria converted the largest amount of energy back to the detritus groups, which had the lowest ecotrophic efficiency (0.01). When aggregating the network to discrete trophic levels (TLs), most of the throughput and biomass of the system were distributed on the first 2 TLs; consequently, there was high energy transfer efficiency between TL I and II $(81.98 \%)$. The trophic flow of this ecosystem was dominated by energy that originated from the detritus groups $(73.77 \%)$. Imported artificial food was particularly important for the trophic flow of the total ecosystem, contributing $31.02 \%$ to total system consumption. The trophic network of the polyculture ecosystem had a moderate Finn's cycling index (17.44\%), a relatively low connectance index (CI: $26.70 \%$ ), and a low system omnivory index (SOI: 0.08). Relative ascendancy was estimated as $44.90 \%$ in this model. Overall, ecosystem properties (i.e. CI, SOI, and relative ascendancy) showed that the artificial 4-species polyculture system represents a simple and fragile, but also 'balanced,' ecosystem.
\end{abstract}

KEY WORDS: Energy flow $\cdot$ Trophic structure $\cdot$ Ecopath $\cdot$ Polyculture $\cdot$ Portunus trituberculatus

\section{INTRODUCTION}

The swimming crab Portunus trituberculatus is one of China's 3 major crab species used in aquaculture (Song et al. 2006) and is widely cultured on the coast of China, with production reaching $117772 \mathrm{t}$ in 2015 (FDAMC 2016). Pond culture is the main culture mode for this species in China (Shi et al. 2010). In the pond culture of $P$. trituberculatus, individual crabs are often polycultured with other organisms, such as shrimp, clams, and fish, due to various ecological and

${ }^{*}$ Corresponding author: xianglitian@ouc.edu.cn economic benefits over monoculture systems when suitable farming densities are used (K. Zhang et al. 2016). Such benefits include improved food resource utilization, increased aquatic production, and enhanced water quality (Dong 2015). Among the different polyculture modes associated with $P$. trituberculatus, the inclusion of white shrimp Litopenaeus vannamei, short-necked clam Ruditapes philippinarum, and redlip mullet Liza haematochila has proven highly effective. $P$. trituberculatus is often fed with imported feed (blue clam Aloidis laevis), the

(C) The authors 2017. Open Access under Creative Commons by Attribution Licence. Use, distribution and reproduction are unrestricted. Authors and original publication must be credited. 
uneaten remains of which are a very good food source for L. vannamei. $R$. philippinarum inhabits the bottom habitat of ponds, whereas L. haematochila uses the upper part of the water column. Both of these species mainly feed on phytoplankton and detritus particles (Xu et al. 1987, K. Zhang et al. 2016). As a result, the polyculture of these 4 culture organisms at suitable farming densities could facilitate the effective use of both food and space resources in this pond ecosystem. However, insufficient data and instruction are currently available on how to optimize these aquaculture activities. Consequently, cultured organisms are often stocked by farmers empirically, with activities failing to reach potential ecological efficiency and economic benefits (Feng et al. 2015). Thus, during the last $5 \mathrm{yr}$, a series of standardized pond aquaculture modes associated with $P$. trituberculatus was explored in a collaboration between the Laboratory of Aquaculture Ecology, Ocean University of China, and related fishery sectors. Within these modes, the polyculture of $P$. trituberculatus with $L$. vannamei, $R$. philippinarum, and L. haematochila represents an optimized mode with suitable farming density.

The ecological characteristics of $P$. trituberculatus aquaculture ponds have been extensively studied in China. These studies include investigations of structural optimization that intended to improve aquaculture production (Zhou et al. 2010, Ban et al. 2015a), energy budgets (Feng et al. 2015), nitrogen and phosphorus budgets (Dong et al. 2013, Zhang et al. 2015a), the organic carbon budget (K. Zhang et al. 2016), and 'emergy' analysis (emergy analysis is a quantitative analysis technique that determines the values of non-monied and monied resources, services, and commodities in common units of solar energy; Ban et al. 2015b). These studies investigated the ecological efficiency of the pond ecosystem. In addition, studies of organic carbon storage (D. Zhang et al. 2016) investigated the structure of the ecosystem, while others have investigated the characteristics of the phytoplankton (Fu et al. 2012), zooplankton (Mao et al. 2014), and bacterioplankton communities (H. Zhang et al. 2008, K. Zhang et al. 2015b). However, most studies have focused on the ecological process of the $P$. trituberculatus ecosystem. Consequently, detailed studies are required on trophic structure and material flow at the ecosystem scale.

Here we used the Ecopath model to develop an ecosystem-based approach to analyze the energy flow and trophic structure of the $P$. trituberculatus polyculture at the ecosystem level. The Ecopath model is an ecosystem approach designed for the straightforward construction, mass-balancing, and analysis of trophic models in aquatic ecosystems (Christensen et al. 2000). The model allows steadystate trophic interactions to be constructed for the respective ecosystems, which helps address knowledge gaps of process-oriented models by pinpointing the questionable estimates of certain parameters (Christensen \& Pauly 1993). To date, the Ecopath model has been widely employed to investigate various types of water bodies globally, including oceans, lakes, and gulfs (Colléter et al. 2015). In contrast, few studies have applied this model to aquaculture pond ecosystems globally or in China. To analyze the energy flow and trophic structure of the $P$. trituberculatus, L. vannamei, $R$. philippinarum, and L. haematochila polyculture system at the ecosystem level, we first quantified the characteristics of the system structure. This aim was achieved by obtaining a steadystate, mass-balanced representation of energy flow and trophic structure over a 90 d culture period. Second, we applied this information to evaluate the $P$. trituberculatus, L. vannamei, $R$. philippinarum, and L. haematochila polyculture ecosystem. We expected our results to demonstrate how the Ecopath model could be used to advance aquaculture practices in China, both from a scientific and a management perspective.

\section{MATERIALS AND METHODS}

\section{Pond and enclosures}

The experiment was conducted using the landbased experimental enclosures in a pond located in Ganyu County, Jiangsu Province, China (345 $58^{\prime} \mathrm{N}$, $119^{\circ} 20^{\prime} \mathrm{E}$ ). The pond was $\sim 0.02 \mathrm{~km}^{2}$ in size, with a water depth of 1.6 to $1.7 \mathrm{~m}$. Four land-based enclosures, representing 4 replicates of the same size (length $\times$ width $\times$ depth $=5 \times 5 \times 2 \mathrm{~m}$ ), were established in the pond and were lined with polyethylene (water-proof material) and supported with wood poles. At the bottom, the square walls of the enclosure were covered with mud from a pond, and supported by posts at $2.5 \mathrm{~m}$ intervals. An aeration system consisting of a blower, PVC tubes, gas tubes, and air stones was used for aeration and water circulation. Five air stones connected by the gas tube were hung in each enclosure, at about $20 \mathrm{~cm}$ from the bottom. The structure of the enclosures was described in detail by Tian et al. (2001) and Wang et al. (1998). The entire experiment was carried out for $90 \mathrm{~d}$ from 13 July to 13 October 2014. 


\section{Cultured animals and aquaculture management}

Juvenile swimming crabs Portunus trituberculatus were cultured with white shrimp Litopenaeus vannamei, redlip mullet Liza haematochila, and shortnecked clam Ruditapes philippinarum in the enclosure ecosystems. All animals were purchased from Ganyu Jiaxin Aquatic Food Co., Ltd. (Ganyu, Jiangsu, China). P. trituberculatus, L. vannamei, L. haematochila, and $R$. philippinarum were stocked in the 4 enclosures at densities of $6,45,3$, and 30 ind. $\mathrm{m}^{-2}$, respectively. The initial individual wet weights of $P$. trituberculatus, L. vannamei, L. haematochila, and $R$. philippinarum were (mean $\pm \mathrm{SD}$ ) $0.57 \pm 0.13,0.045 \pm$ $0.01,0.67 \pm 0.09$, and $0.92 \pm 0.11 \mathrm{~g}$, respectively.

The crabs were fed blue clams Aloidis laevis twice a day (06:00 and 18:00 h). The amount of A. laevis supplied to the crabs changed from 80.00 to $2.00 \%$ of the crab's body weight at different stages of development (Zhou et al. 2010). The shrimp were fed commercial pellets (Lianyungang Chia Tai Feed) twice a day (06:00 and 18:00 h), and the quantity of food used during the experiment changed according to the specifications for use of the pellet product.

To check the growth of crabs and shrimp, 15-20 ind. enclosure $^{-1}$ were sampled at $10 \mathrm{~d}$ intervals. A cage net $(60 \times 40 \times 15 \mathrm{~cm})$ was designed to trap the crabs and shrimp, and the animals were deliberately returned to the enclosure from which they were removed after each sampling event. During the whole culture period, the polyculture ecosystem was kept in a relatively stable state, with no outbreaks of disease being documented. All culture animals were harvested at the end of the experiment. The harvest data are provided by Ban et al. (2015b).

\section{Model construction}

A mass-balanced model was constructed for this aquaculture ecosystem. This model was constructed according to 2 master equations, presenting a static description of energy flow and trophic interactions among different model groups in the ecosystem (Christensen \& Pauly 1992a,b).

The first equation represents the production of each model group that is used in the ecosystem. Production is divided into predation, migration, biomass accumulation, and exports, and is expressed as:

$B_{i} \times\left(\frac{P}{B}\right)_{i} \times E E_{i}-\sum_{j}\left(B_{j} \times\left(\frac{Q}{B}\right)_{j} \times D C_{i j}\right)-Y_{i}-B A_{i}-E_{i}=0$

where $B_{i}$ is the biomass of prey (i) and $B_{j}$ is the biomass of predator $j_{i}(P / B)_{i}$ is the ratio of production to biomass of prey $(i) ; E E_{i}$ is ecotrophic efficiency $(E E)$; $Y_{i}$ is the biomass that is caught; $(Q / B)_{j}$ is the ratio of food consumption to biomass of predator $j_{i} D C_{j i}$ is the proportion of prey $i$ in the food composition of predator $j_{i} B A_{i}$ is the biomass accumulation rate of prey $(i) ;$ and $E_{i}$ is the margin between immigration and emigration of prey $i$.

The second equation represents the consumption of a model group that is composed of production, respiration, and unassimilated food:

$$
B_{i} \times\left(\frac{Q}{B}\right)_{i}=B_{i} \times\left(\frac{P}{B}\right)_{i}+R_{i}+U_{i}
$$

where $R_{i}$ is respiration and $U_{i}$ is the food that is not assimilated. Ecopath requires that at least 3 of these 4 parameters, i.e. $B, P / B, Q / B$, and $E E$, are used (input) in the model. Because it is difficult to obtain $E E$, the other 3 parameters are generally used. A detailed description about the limitations, capabilities, and methods of this model is provided by Christensen \& Walters (2004).

\section{Model groups}

Based on the definition for model groups and the setting principles of the Ecopath model, 18 model groups were used in this $P$. trituberculatus polyculture ecosystem. Phytoplankton was divided into 3 groups: pico- $(<10 \mu \mathrm{m})$, nano- $(10-38 \mu \mathrm{m})$, and microphytoplankton $(>38 \mu \mathrm{m})$. Zooplankton were divided into 2 groups: macro- (copepods and planktonic mollusks, $>150 \mu \mathrm{m}$ ) and microzooplankton (copepodites and rotifers, $<150 \mu \mathrm{m}$ ). Zoobenthos were divided into 2 groups: macro- (polychaetes $>500 \mu \mathrm{m}$ ) and microbenthos (polychaetes and nematodes $<500 \mu \mathrm{m}$ ). Bacteria were divided into 2 groups: benthic bacteria and bacterioplankton. Detritus was divided into 2 groups: detritus in sediment and detritus in water. An energy flow pathway was set such that the energy of detritus in water, which was not used by recycling $\left(1-E E_{i}\right)$, ultimately flowed to detritus in the sediment. The remaining model groups were: $P$. trituberculatus, L. vannamei, R. philippinarum, L. haematochila, periphyton, A. laevis, and shrimp feed. The imported foods, i.e. A. laevis and shrimp feed, were set as detritus groups.

\section{Field data}

For all the model groups, the input data of the model required biomass, $P / B$ ratio, $Q / B$ ratio, and the diet matrix of consumers. Most of the input data were 
obtained from the field experiment, and all input data were calculated as the average value of the $90 \mathrm{~d}$ culture period.

The biomass for each model group, expressed as kJ $\mathrm{m}^{-2}$, was mainly obtained from field surveys conducted every $30 \mathrm{~d}$, except for L. haematochila and $R$. philippinarum, which were calculated from the initial weight and harvesting weight. The production of $P$. trituberculatus, L. vannamei, $R$. philippinarum, and L. haematochila was obtained by calculating the initial weight and the weight at harvest. All $P / B$ values of the phytoplankton groups and periphyton were estimated by using the 'light and dark bottle' oxygen method (Diana et al. 1991). The $P / B$ value of bacterioplankton was obtained from the field experiment by following the method of Schwaerter et al. (1988). The $P / B$ values of the zooplankton groups and benthic bacteria were calculated by converting $P / Q$ values obtained from Straile (1997) and Moriarty (1986), respectively. The $P / B$ values of macro- and microbenthos were obtained based on Zhou \& Xie (1995) and Schwinghamer et al. (1986), respectively.

The $Q / B$ values of $P$. trituberculatus (Yang et al. 2010) and L. vannamei (Qi et al. 2010) were calculated from the daily food consumption. The $Q / B$ values of macrozooplankton, microzooplankton, and bacterioplankton were calculated from their respiration, based on Williams (1981). The $Q / B$ of benthic bacteria was estimated from respiration, assuming that the respiration of benthic bacteria accounts for 0.64 of sediment respiration (Hargrave 1972). Sediment respiration was measured following the methods of Li \& Lu (1998). The $Q / B$ values of $R$. philippinarum, L. haematochila, macrobenthos, and microbenthos were adopted from Zhang \& Yan (2010), Li et al. (1995), and Lin (2012), respectively. For details on how the input data were obtained, see the section entitled 'Input data of $B, P / B$, and $Q / B$ ' in the Supplement at www.int-res.com/articles/suppl/q009 p479_supp.pdf.

The diets of $P$. trituberculatus, $L$. vannamei, $L$. haematochila, macrobenthos, microbenthos, macrozooplankton, and microzooplankton were mainly obtained from carbon stable isotopes, with some adjustments for $P$. trituberculatus following Yang (2001), for R. philippinarum following Wetzel (1983) and Zhang et al. (2005), for L. haematochila following Liu \& Li (1999), for macrobenthos following Wang \& Zhang (1998) and Tsuchiya \& Kurihara (1979), for microbenthos following Jin (2010), and for macroand microzooplankton following Li \& Lin (1995). The diets of benthic bacteria and bacterioplankton were assembled from a previous study by Zhou (2015). The diet composition was expressed as the proportion of each consumer group, and is detailed in Table 1. Details on how the diets were obtained are provided in the 'Diet composition' section of the Supplement.

Table 1. Diet composition of the consumers in a 4-species polyculture ecosystem model. The proportion of each prey group in the predator's diet is indicated by the displayed values (blanks = zero). Pot: Portunus trituberculatus; Liv: Litopenaeus vannamei; Rup: Ruditapes philippinarum; Lih: Liza haematocheli; Mab: macrobenthos; Mib: microbenthos; Maz: macrozooplankton; Miz: microzooplankton; Beb: benthic bacteria; Bap: bacterioplankton; Mip: micro-phytoplankton; Nap: nano-phytoplankton; Pip: pico-phytoplankton; Pep: periphyton; All: Aloidis laevis; Shf: shrimp feeds; Des: detritus in sediment; Dew: detritus in water

\begin{tabular}{|c|c|c|c|c|c|c|c|c|c|c|c|}
\hline \multirow{2}{*}{ Number } & \multirow{2}{*}{ Prey/predator } & \multicolumn{10}{|c|}{ - Number } \\
\hline & & 1 & 2 & 3 & 4 & 5 & 6 & 7 & 8 & 9 & 10 \\
\hline 1 & Pot & & & & & & & & & & \\
\hline 2 & Liv & & & & & & & & & & \\
\hline 3 & Rup & & & & & & & & & & \\
\hline 4 & Lih & & & & & & & & & & \\
\hline 5 & Mab & 0.001 & & & & & & & & & \\
\hline 6 & Mib & & & & & 0.077 & & & & & \\
\hline 7 & Maz & 0.029 & 0.010 & & 0.038 & & & & & & \\
\hline 8 & Miz & & & & 0.034 & & & 0.130 & & & \\
\hline 9 & Beb & & & & & 0.054 & 0.650 & & & & \\
\hline 10 & Bap & & & 0.140 & 0.050 & & & 0.270 & 0.088 & & \\
\hline 11 & Mip & & 0.020 & 0.171 & 0.183 & & & 0.090 & 0.184 & & \\
\hline 12 & Nap & & 0.020 & 0.183 & 0.176 & & & 0.100 & 0.194 & & \\
\hline 13 & Pip & & 0.020 & 0.189 & 0.194 & & & 0.100 & 0.193 & & \\
\hline 14 & Pep & & & & 0.034 & 0.009 & & 0.000 & 0.012 & & \\
\hline 15 & All & 0.970 & 0.330 & & & 0.233 & 0.100 & 0.271 & & & \\
\hline 16 & Shf & & 0.580 & & & & & & 0.104 & & \\
\hline 17 & Des & & 0.020 & 0.062 & 0.153 & 0.627 & 0.250 & 0.039 & 0.095 & 0.950 & 0.050 \\
\hline 18 & Dew & & & 0.255 & 0.138 & & & & 0.130 & 0.050 & 0.950 \\
\hline
\end{tabular}


A default value of 0.4 was adopted for the unassimilated values of macrobenthos, macrozooplankton, and microzooplankton, 0.3 for L. haematochila and microbenthos, and 0.2 for most of the other consumers (Winberg 1956, Bradford-Grieve et al. 2003).

\section{Model balancing and uncertainties}

We used the estimated $E E$ value of each functional group (which was $<1$ ) in the first attempt to balance the model. If the estimated $E E$ value exceeds 1 , the consumed biomass is greater than that produced. When this occurred, the input data of the diet composition for each consumer group was modified with small changes, with each change not exceeding 0.05 . Furthermore, we ensured that most of the $P / Q$ values (the gross food conversion efficiency, i.e. the ratio between production and consumption) were in the range of $0.1-0.3$. We also ensured that the respiration to assimilation $(R / A)$ and production to respiration $(P / R)$ ratios in the model were $<1$; the respiration to biomass $(R / B)$ ratio is higher in active species than in sedentary groups (Christensen et al. 2005, Link 2010, 2016, Heymans et al. 2016). For detailed information on the processes used, see 'Balancing the Ecopath model' in the Supplement. The validity and dependency of the input values were then verified by running the pedigree routine for the model following Funtowicz \& Ravetz (1990), which described the data origin and assigned a confidence interval to each of the data sets in terms of their origin (Pauly et al. 2000). The estimated pedigree index $P$ was obtained according to the following equation:

$$
P=\sum_{i=1}^{n} \sum_{j=1} l_{i j}
$$

where $l_{i j}$ is the pedigree index of functional group $i$ and parameter $j$, and $n$ is the number of all model groups.

\section{Ecological indicators}

Ecopath contains a series of indices that are based on concepts developed by theoretical ecologists to assess the system structure and energy flow in an ecosystem (Ulanowicz 1986).

Total system throughput (TST) is the sum of all flows in the model and is considered an overall measure of the ecological size of the ecosystem. This measure is the sum of the 4 flow components: (1) sum of all consumption; (2) sum of all exports, i.e. ex- ported from the system by fisheries or sedimented; (3) sum of all respiration flows; and (4) sum of all flows into detritus. EE values were calculated as the fraction of production that is consumed within or exported out of the system. The transfer efficiency (TE) is calculated as the ratio between the sum of the exports from a given trophic level (TL), plus the flow that is transferred from one TL to the next, and the throughput on the TL (Christensen et al. 2005). The connectance index (CI) and the system omnivory index (SOI) are correlated with system maturity, since a food chain is expected to change from linear to web-like as the system matures (Odum 1971, Christensen et al. 2000). CI is the ratio of the number of actual links to the number of all possible links. SOI is calculated as the variance of the TL of a consumer's prey groups. Finn's cycling index (FCI) represents the proportion of the total throughput that is recycled in the ecosystem (Christensen et al. 2005).

\section{RESULTS}

\section{Ecological indicators of each model group}

The ecological indicators of each functional group in this ecosystem are presented in Table 2. The EE value of each functional group ranged considerably, from 0.01 to 1 . Among the different model groups, the lowest $E E$ values were obtained for benthic bacteria (0.01) and microbenthos (0.05), indicating that these groups were generally not consumed by any other groups in this ecosystem. The EE values were also low for pico-phytoplankton (0.24) and nano-phytoplankton (0.30). In contrast, the blue clam Aloidis laevis, detritus in sediment, and shrimp feed groups had high EE values (e.g. 0.99, 0.96, and 0.96, respectively), suggesting that most of these groups were consumed. Because the biomass of the swimming crab, white shrimp, short-necked clam, and redlip mullet was harvested at the end of the experiment, these 4 species all expressed high EE values (e.g. 0.83, 0.96, 0.90, and 0.97, respectively). Other groups with relatively high $E E$ values included macrozooplankton (0.91), macrobenthos (0.86), and periphyton (0.84). The lowest gross food conversion efficiency $(P / Q)$ value was obtained for $R$. philippinarum (0.06), whereas the highest $P / Q$ value was obtained for bacterioplankton (0.34). The ratios of production to respiration $(P / R)$ and respiration to assimilation $(R / A)$ for all groups were $<1$, supporting the principles used to accept the present Ecopath model. 


\section{Trophic structure and flows}

The 18 groups used in Ecopath were aggregated into 5 integer TLs by using the trophic aggregation routine in this ecosystem (Table 3). TL I in this ecosystem was composed of primary producers, including micro-, nano-, and pico-phytoplankton, periphyton, and the detritus groups of A. laevis, shrimp feed, detritus in sediment, and detritus in water. Approximately $73.77 \%$ of the energy flow of the system originated from the detritus groups $(28596.00 \mathrm{~kJ})$, whereas the remaining $26.23 \%$ originated from primary producers (10 168.10 kJ). Energy flows in TL II encompassed almost all of the consumer groups in this study, except microbenthos, which had greater relevance at TL III. Although there were 5 discrete TLs, most of the energy flow of the 18 groups was distributed in TL I and II. Energy flow at TL IV and V was negligible.

One of the Ecopath model outputs was the effective TL, which was calculated through the weighted average of the TLs of each prey item. The detritus groups and primary producers were set at a TL of 1 in this model. In comparison, the TL of the consumer groups was set at $1+$ (weighted average of the TL of the prey) (Odum \& Heald 1975). The effective TL of all model groups ranged from 1 to 2.65 , with microbenthos having the highest TL in this ecosystem. The TLs of all other consumers were closer to TL 2 (Fig. 1).

With respect to energy flow to the detritus groups of each functional group, the highest flow to detritus was obtained for the benthic bacteria group, followed by nano- and pico-phytoplankton (Table 3). The flow diagram resulting from the model represents each functional group with a circle that is proportional to the logarithm of its biomass (Fig. 1). The prey and predator interactions of all groups are shown in Fig. 1.
Table 2. Ecopath outputs for the 4-species polyculture ecosystem model. Values in omass; $P / B$ : production/biomass; $Q / B$ : consumption/biomass; EE: ecotrophic effiency; $P / Q$ : production/consumption; $R / A$ : respiration/assimilation; $P / R$ : production/ spiration. $P / B, Q / B$ and detritus import were calculated for the $90 \mathrm{~d}$ experimental period

\begin{tabular}{|c|c|c|c|c|c|c|c|c|}
\hline $\begin{array}{l}\text { Group } \\
\text { name }\end{array}$ & $\begin{array}{c}B \\
\left(\mathrm{~kJ} \mathrm{~m}^{-2}\right)\end{array}$ & $\begin{array}{c}P / B \\
\left(90 \mathrm{~d}^{-1}\right)\end{array}$ & $\begin{array}{c}Q / B \\
\left(90 \mathrm{~d}^{-1}\right)\end{array}$ & $E E$ & $P / Q$ & $R / A$ & $P / R$ & $\begin{array}{l}\text { Detritus import } \\
\left(\mathrm{kJ} \mathrm{m}^{-2} 90 \mathrm{~d}^{-1}\right)\end{array}$ \\
\hline Pot & 525.78 & 1.99 & 6.03 & 0.83 & 0.33 & 0.59 & 0.70 & \\
\hline Liv & 531.78 & 1.99 & 13.49 & 0.96 & 0.15 & 0.82 & 0.23 & \\
\hline Rup & 40.73 & 1.53 & 27.60 & 0.90 & 0.06 & 0.92 & 0.08 & \\
\hline Lih & 138.35 & 1.86 & 18.38 & 0.97 & 0.10 & 0.87 & 0.14 & \\
\hline Mab & 0.57 & 6.44 & 21.47 & 0.86 & 0.30 & 0.63 & 0.60 & \\
\hline Mib & 2.08 & 9.23 & 30.76 & 0.05 & 0.30 & 0.62 & 0.60 & \\
\hline Maz & 7.09 & 40.50 & 139.65 & 0.91 & 0.29 & 0.52 & 0.94 & \\
\hline Miz & 2.73 & 108.00 & 372.41 & 0.73 & 0.29 & 0.52 & 0.94 & \\
\hline Beb & 144.50 & 28.80 & 95.40 & 0.01 & 0.30 & 0.62 & 0.61 & \\
\hline Bap & 15.53 & 66.60 & 197.10 & 0.62 & 0.34 & 0.58 & 0.73 & \\
\hline Mip & 10.71 & 148.50 & 0.00 & 0.68 & & & & \\
\hline Nap & 20.94 & 171.90 & 0.00 & 0.30 & & & & \\
\hline Pip & 16.83 & 288.90 & 0.00 & 0.24 & & & & \\
\hline Pep & 11.93 & 9.90 & 0.00 & 0.84 & & & & \\
\hline All & 64.15 & & & 0.99 & & & & 5773.50 \\
\hline Shf & 49.40 & & & 0.96 & & & & 4446.00 \\
\hline Des & 5722.01 & & & 0.96 & & & & \\
\hline Dew & 245.80 & & & 0.44 & & & & \\
\hline
\end{tabular}

Table 3. Trophic flow matrix of the 4-species polyculture ecosystem according to model groups and trophic levels. Group names as in Table 1. FD: flow to detritus (calculated for the $90 \mathrm{~d}$ experimental period); ETL: effective trophic level

\begin{tabular}{|c|c|c|c|c|c|c|c|}
\hline \multirow{2}{*}{$\begin{array}{l}\text { Group } \\
\text { name }\end{array}$} & \multicolumn{5}{|c|}{ - Trophic level } & \multirow{2}{*}{$\begin{array}{c}\text { FD } \\
\left(\mathrm{kJ} \mathrm{m}^{-2} 90 \mathrm{~d}^{-1}\right)\end{array}$} & \multirow[t]{2}{*}{ ETL } \\
\hline & I & II & III & IV & V & & \\
\hline Pot & 0.00 & 3075.00 & 57.92 & 35.98 & 1.21 & 816.42 & 2.04 \\
\hline Liv & 0.00 & 7102.00 & 43.04 & 27.87 & 0.82 & 1477.24 & 2.01 \\
\hline Rup & 0.00 & 966.70 & 157.40 & 0.00 & 0.00 & 309.62 & 2.14 \\
\hline Lih & 0.00 & 2233.00 & 264.00 & 45.15 & 1.11 & 517.51 & 2.14 \\
\hline Mab & 0.00 & 10.63 & 0.99 & 0.61 & 0.00 & 2.95 & 2.18 \\
\hline Mib & 0.00 & 22.39 & 41.58 & 0.00 & 0.00 & 31.05 & 2.65 \\
\hline Maz & 0.00 & 594.30 & 384.90 & 11.33 & 0.00 & 422.91 & 2.41 \\
\hline Miz & 0.00 & 927.10 & 89.46 & 0.00 & 0.00 & 486.23 & 2.09 \\
\hline Beb & 0.00 & 13786.00 & 0.00 & 0.00 & 0.00 & 6876.41 & 2.00 \\
\hline Bap & 0.00 & 3061.00 & 0.00 & 0.00 & 0.00 & 1005.16 & 2.00 \\
\hline Mip & 1590.00 & 0.00 & 0.00 & 0.00 & 0.00 & 513.23 & 1.00 \\
\hline Nap & 3599.00 & 0.00 & 0.00 & 0.00 & 0.00 & 2506.62 & 1.00 \\
\hline Pip & 4861.00 & 0.00 & 0.00 & 0.00 & 0.00 & 3717.73 & 1.00 \\
\hline Pep & 118.10 & 0.00 & 0.00 & 0.00 & 0.00 & 19.34 & 1.00 \\
\hline All & 5773.00 & 0.00 & 0.00 & 0.00 & 0.00 & 53.25 & 1.00 \\
\hline Shf & 4446.00 & 0.00 & 0.00 & 0.00 & 0.00 & 179.57 & 1.00 \\
\hline Des & 14010.00 & 0.00 & 0.00 & 0.00 & 0.00 & 557.50 & 1.00 \\
\hline Dew & 4367.00 & 0.00 & 0.00 & 0.00 & 0.00 & 5641.38 & 1.00 \\
\hline Total & 38764.10 & 31778.12 & 1039.29 & 120.94 & 3.14 & 25174.12 & \\
\hline
\end{tabular}




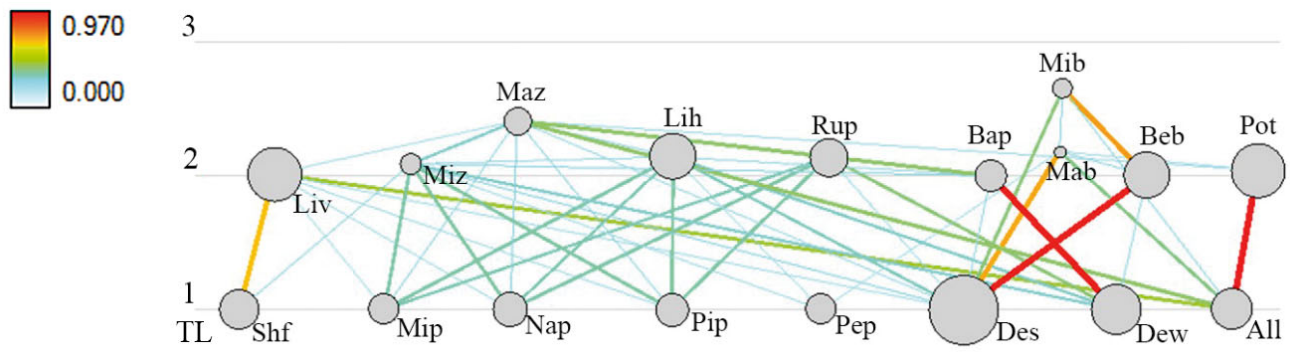

Fig. 1. Ecopath outputs based on the food web conceptualization of the 4 -species polyculture ecosystem. The thickness and color of the lines illustrate the magnitude of the flow rates; the color key (dimensionless) represents the proportion that the prey contributed to a predator's diet. Circle sizes are proportional to logarithm of biomass. TL: trophic level; group abbreviations as in Table 1
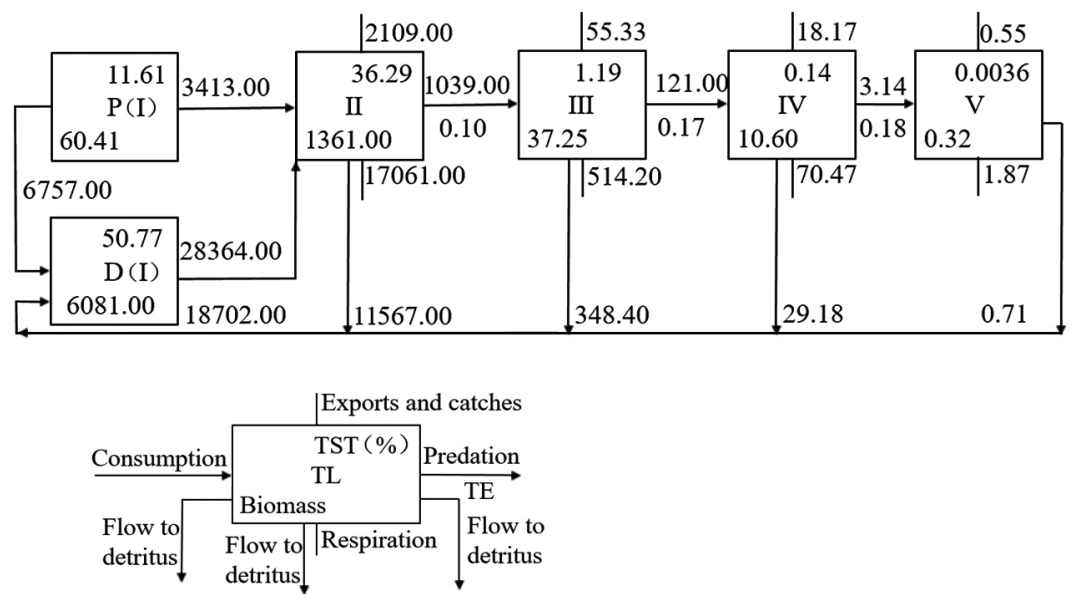

Fig. 2. Aggregation of flows and biomass $\left(\mathrm{kJ} \mathrm{m}^{-2} 90 \mathrm{~d}^{-1}\right)$ in the 4 -species polyculture ecosystem into discrete trophic levels (I to V) sensu Lindeman (1942). D: detritus; P: primary producers; TL: trophic level; TE: transfer efficiency, TST: total system throughput; export and catches: harvest of cultured animals

biomass (excluding detritus), highlighting the importance of TL II. The TST of TL II was $36.29 \%$, while the TE from TL II to TL III was $10.00 \%$ (Fig. 2), which was equal to the $10.00 \%$ often assumed to exist in natural ecosystems (Lindeman 1942).

\section{Ecosystem analysis and indicators}

To describe the characteristics of system structure and size in this ecosystem, key attributes of the model were examined (Table 4). The TST estimated for this polyculture ecosystem was $87588.29 \mathrm{~kJ} \mathrm{~m}^{-2}$ over the $90 \mathrm{~d}$ experiment. The energy that flowed to detritus accounted for the

The Lindeman spine plot of flow and biomass is shown in Fig. 2. Most of the system throughput was located at TLs I and II (Fig. 2), which collectively accounted for $98.67 \%$ of the TST. Even though the biomass of all primary producers $\left(60.41 \mathrm{~kJ} \mathrm{~m}^{-2}\right)$ was just $4.11 \%$ of the total biomass (excluding detritus), the production of this biomass contributed $11.61 \%$ of TST, due to the high turnover rate of production. The total primary production of the ecosystem was calculated to be $10170.00 \mathrm{~kJ} \mathrm{~m}^{-2}$ over the $90 \mathrm{~d}$ experiment, of which $6757.00 \mathrm{~kJ} \mathrm{~m}^{-2}(66.43 \%)$ flowed to the detritus group, and $3413.00 \mathrm{~kJ} \mathrm{~m}^{-2}$ (33.57\%) was dedicated to the consumption of consumers at TL II (Fig. 2). The throughput associated with detritus (including imported food) contributed to the largest percentage of TST (50.77\%). Out of all of the energy that flowed to the detritus groups, approximately $98.07 \%$ (28364.00 $\mathrm{kJ} \mathrm{m}^{-2}$ over the $90 \mathrm{~d}$ experiment) was reutilized and flowed to TL II. The remaining $1.93 \%\left(557.50 \mathrm{~kJ} \mathrm{~m}^{-2}\right)$ represented biomass accumulation in the detritus in sediment group. The biomass at TL II represented approximately $92.61 \%$ of total largest part of TST (39.73\%), while $37.61 \%$ was attributed to consumption, $20.15 \%$ to respiration, and $2.49 \%$ to exports.

The ratio of total primary production to total respiration was 0.58 , indicating that total primary production was lower than total respiration. Consequently, net system production during the $90 \mathrm{~d}$ experiment was negative at $-7477.63 \mathrm{~kJ} \mathrm{~m}^{-2}$.

The SOI and system CI were 0.08 and $26.70 \%$, respectively. Finn's mean path length was 4.42 . The amount of recycled system throughput, or FCI, was $17.44 \%$, indicating that $17.44 \%$ of TST was recycled (Finn 1976). The pedigree index (0.82) of the model was higher than the range (0.16-0.68) of the 150 Ecopath models suggested by Morissette et al. (2007), validating that the input data were sufficient and reliable to parameterize the model. The system ascendancy, which represents both the size and the organization of flow in this ecosystem, was calculated as 187584.20 flowbits (Christensen et al. 2005). The overhead was estimated as 229951.30 flowbits; this value was the margin between ascendancy and total 
Table 4. Ecosystem indicators describing the 4-species polyculture ecosystem structure. Units were calculated over the $90 \mathrm{~d}$ experimental period

\begin{tabular}{|c|c|c|}
\hline Parameter & Value & Units \\
\hline \multicolumn{3}{|l|}{ Ecosystem theory indices } \\
\hline Total system throughput & 87588.29 & $\mathrm{~kJ} \mathrm{~m}^{-2}$ \\
\hline Sum of all consumption & 32940.32 & $\mathrm{~kJ} \mathrm{~m}^{-2}$ \\
\hline Sum of all respiratory flows & 17647.94 & $\mathrm{~kJ} \mathrm{~m}^{-2}$ \\
\hline Sum of all flows into detritus & 34795.32 & $\mathrm{~kJ} \mathrm{~m}^{-2}$ \\
\hline Sum of all exports & 2183.74 & $\mathrm{~kJ} \mathrm{~m}^{-2}$ \\
\hline Sum of all production & 28614.10 & $\mathrm{~kJ} \mathrm{~m}^{-2}$ \\
\hline Calculated total net primary production & 10170.32 & $\mathrm{~kJ} \mathrm{~m}^{-2}$ \\
\hline Net system production & -7477.63 & $\mathrm{~kJ} \mathrm{~m}^{-2}$ \\
\hline Total biomass (excluding detritus) & 1469.55 & $\mathrm{~kJ} \mathrm{~m}^{-2}$ \\
\hline Total primary production/total respiration & 0.58 & Unitless \\
\hline Total primary production/total biomass & 6.92 & Unitless \\
\hline Connectance index & 26.70 & $\%$ \\
\hline System omnivory index & 0.08 & Unitless \\
\hline Ecopath pedigree index & 0.82 & Unitless \\
\hline \multicolumn{3}{|l|}{ Cycling indices } \\
\hline Finn's mean path length & 4.42 & Unitless \\
\hline $\begin{array}{l}\text { Finn's straight-through path length } \\
\text { (with detritus) }\end{array}$ & 1.23 & Unitless \\
\hline $\begin{array}{l}\text { Finn's straight-through path length } \\
\text { (no detritus) }\end{array}$ & 3.65 & Unitless \\
\hline Finn's cycling index & 17.44 & $\%$ \\
\hline \multicolumn{3}{|l|}{ Informational indices } \\
\hline Ascendancy & 187584.20 & Flowbits \\
\hline Overhead & 229951.30 & Flowbits \\
\hline Total capacity & 417499.10 & Flowbits \\
\hline Relative ascendancy & 44.90 & $\%$ \\
\hline Relative overhead & 55.10 & $\%$ \\
\hline
\end{tabular}

$\left.E E_{i}\right)$, ultimately flowed to detritus in the sediment. This assumption was reasonable because our field observations showed almost no biomass accumulation for detritus in water at the end of the experiment. However, model estimates of the consumption of detritus in water at TL II were significantly lower than the energy channeled into this group. Therefore, an energy pathway might exist between the 2 detritus groups (e.g. detritus in water and detritus in sediment). Furthermore, our field observations of the biomass of detritus in sediment at the end of the experiment supported the model outputs based on this assumption (J. Feng unpubl. data), further supporting this assumption in the model.

$E E$ was calculated as the fraction of production that was exported out of the ecosystem or passed up through the food web (Coll et al. 2009). As a result, most of the $E E$ values in this ecosystem were estimated as being higher than 0.6, indicating a generally high energy utilization efficiency. EE values above 0.5 are unlikely to occur in natural ecosystems, as they would be unstable (Dickie 1972).

development capacity, and provides limits on the increase in ascendancy and reflects the system's 'strength in reserves' that it draws to meet unexpected perturbations (Ulanowicz 1986). The relative ascendancy $(\mathrm{A} / \mathrm{C})$ and the relative overhead were calculated as 44.90 and $55.10 \%$, respectively.

\section{DISCUSSION}

To date, few studies on ecosystem properties have focused on pond aquaculture ecosystems. Pond aquaculture ecosystems are semi-artificial ecosystems that are constructed, and have certain attributes (such as shallow and small water bodies, simple composition of the biological community, high primary productivity, and abundant imported organic material) that are not present in natural systems (Dong \& Zhao 2004). The application of the Ecopath model to study the characteristics of energy flow and trophic structure of such a pond aquaculture ecosystem will help us to understand the properties and energy utilization of the system, and thereby improve it.

In this study, we assumed that the energy of detritus in water, which was not utilized by recycling (1 -
However, 2 management practices conducted in our aquaculture ecosystem might contribute towards maintaining ecosystem stability. First, a high quantity of available resources (i.e. the blue clam Aloidis laevis and shrimp feed) was imported to the ecosystem to support the food web (Bayle-Sempere et al. 2013), and promoted the system's ability to meet unexpected perturbations (Ulanowicz 1986). Second, by increasing dissolved oxygen concentration through aerating water and bottom sediments, the microbial oxidation of organic matter was enhanced, possibly contributing to ecosystem stability (Ghosh \& Mohanty 1981, Ayub et al. 1993). Among the food resources, most benthic bacteria and phytoplankton (e.g. nanoand pico-phytoplankton) were underutilized, channeling significant amounts of energy to the detritus groups. The low utilization of benthic bacteria might be attributed to the low biomass of consumer-microbenthos and macrobenthos. In contrast, the low EE values of nano- and pico-phytoplankton might be due to their high productivity boosted by large quantities of waste from excretion by cultured animals, which was converted to fertilizer for phytoplankton (Lorenzen et al. 1997, Wang et al. 2001). Even though phytoplankton accounted for a large proportion of 
consumption by the short-necked clam and redlip mullet, productivity still exceeded consumption rates. Thus, it might be beneficial to culture higher densities of clams and mullet in this ecosystem.

One of the most prominent characteristics of the system structure was that most of the system throughput and biomass were distributed in TL I and II. Consequently, the trend of trophic TE was expressed as: high TE $(81.98 \%)$ between lower TLs (I and II) and lower TE between higher TLs (TL II to V). This trend in trophic TE was similar to that of many lake ecosystems, such as Lake Victoria, Lake Malawi, and Lake Kinneret (Christensen \& Pauly 1993), Lake Qiandaohu (Liu et al. 2007), and Lake Hayq (Fetahi et al. 2011). The high TE between TL I and II was partially due to the high utilization of imported food, which was primarily consumed by the cultured organisms, i.e. swimming crab and white shrimp. In comparison, the high TE between TL I and II was also associated with high consumption rates by bacterioplankton and benthic bacteria. These 2 consumer types collectively used up $90.12 \%$ of the energy that flowed into the detritus groups of detritus in sediment and detritus in the water in this ecosystem, indicating the importance of the microbial loop in this ecosystem. Liu \& Li (1999) and Costa-Pierce et al. (1984) found that bacterioplankton had higher consumption rates than benthic bacteria in a shrimp pond ecosystem. In contrast, the benthic bacteria consumption rates were approximately 4.5-fold higher than that of bacterioplankton in our aquaculture ecosystem. This result indicates that the microbial loop was closely associated with the benthic bacteria group. This phenomenon might be due to differences in cultured animals, bottom soil conditions, and management practices among different aquaculture ecosystems.

Another remarkable characteristic of the ecosystem structure was the dominant position of the detritus food chain within the food web. The energy originating from detritus accounted for $73.77 \%$ of total energy flow, of which just $26.23 \%$ originated from primary producers. This feature was probably caused by the imported food, i.e. A. laevis and shrimp feed. The imported food played an important role in the ecosystem, contributing to $31.02 \%$ of total system consumption, corresponding to $97.00 \%$ for Portunus trituberculatus, $91.00 \%$ for Litopenaeus vannamei, $27.10 \%$ for macrozooplankton, and $10.40 \%$ for macrobenthos, respectively. Consequently, the energy input of imported food greatly reduced the dependency of the ecosystem on primary production (BayleSempere et al. 2013). This phenomenon might also cause the average path length to decrease in this ecosystem, due to the short energy path length associated with imported food (Zhou et al. 2016).

Most of the consumers in this ecosystem were detritivores or herbivores, with the lack of carnivores as higher TL consumers being another characteristic of this ecosystem. This characteristic signifies that higher consumers do not act as couplers of distinct energy channels, leading to differences in both the productivity and the turnover rate in this ecosystem (Rooney et al. 2006). This characteristic suggested that the food chain in this ecosystem is distinguished by a linear feature, rather than a web-like feature. According to Rooney et al. (2006), the heterogeneity of distinct energy channels and the presence of higher-order consumers to couple distinct channels are essential to maintain ecosystem stability. The lack of higher-order consumers in our ecosystem indicated that the stability was fragile.

The Ecopath model provided several information indices that characterized the overall status of the system (Table 4). The $\mathrm{CI}$ and SOI values were $26.70 \%$ and 0.08 , respectively, in this study. The low values of these 2 indices supported our suggestion that this ecosystem had a linear food web structure, rather than a web-like structure (Hossain et al. 2010, $\mathrm{Xu}$ et al. 2011). Particularly, the SOI (0.08) in our study was lower than most of the SOI values of the 105 published Ecopath with Ecosim models investigated by Heymans et al. (2014), indicating a simple system structure. The FCI was $17.44 \%$ in our study, which was considered moderate when compared to the FCI values in the small ecosystems $\left(1-10 \mathrm{~km}^{2}\right)$ investigated by Heymans et al. (2014), but higher than many FCI values in large ecosystems. The energy that flowed to detritus was the highest system throughput in this study, which supports the suggestion by Heymans et al. (2014) that shallow ecosystems tend to have high values of energy flow to detritus over TST. However, the ratio of total respiration to TST was also high in our study, contrary to the suggestion by Heymans et al. (2014) that the ratio of total respiration to TST is low in shallow ecosystems. The A/C, which indicated a level of system organization and efficiency (Ulanowicz 1997, 2004), commonly occurs at 35 to $45 \%$ in most ecosystems (Ray 2008). The $\mathrm{A} / \mathrm{C}$ in our 4 -species polyculture ecosystem was estimated as $44.90 \%$, indicating a relatively high level of organization. Ulanowicz et al. (2009) suggested that a sustainable ecosystem is required to retain a balance between its organization and resilience, with an optimal A/C of $45.96 \%$ based on information theory. The $\mathrm{A} / \mathrm{C}$ value of $44.90 \%$ in our ecosystem suggests 
that the level of system organization and resilience was well-balanced and conformed to the requirements for sustainable development. This value also implies that the polyculture of cultured organisms and the aquaculture management of this artificial ecosystem were reasonable.

In general, traditional process-oriented models used in aquaculture are very useful for describing component processes, connecting these processes, and synthesizing these processes to represent ecosystems (Christensen \& Pauly 1993). However, such models are incapable of describing large integrated ecosystems and making predictions at the ecosystem level. To our knowledge, our study represents the first attempt to investigate the energy flow and trophic structure of a $P$. trituberculatus polyculture pond ecosystem using the Ecopath model at the ecosystem level. Several ecosystem properties indicated that this 4-species polyculture ecosystem was fragile and simple, but also balanced, with a linear food chain. Our results demonstrate the suitability of using the Ecopath model to understand ecosystem characteristics in terms of energy flow and trophic structure. Future studies could advance present knowledge of ecosystem properties by integrating organic resources and inorganic nutrition. In conclusion, the current study demonstrates the utility of the Ecopath model to elucidate the dynamics of aquaculture ecosystems and improve management and production.

Acknowledgements. This study was supported by the National Great Project of Scientific and Technical Supporting Programs (Grant No. 2011BAD13B03) and the Programs for Excellent Youth Foundation of Shandong Province (Grant No. JQ201009). We thank Mingliang Gao, Wenbo Ban, and Run Wang for help with experimental management and sampling, and Hongyan Zhang for helping us to construct the Ecopath model.

\section{LITERATURE CITED}

Ayub M, Boyd CE, Teichert-Coddington D (1993) Effects of urea application, aeration, and drying on total carbon concentrations in pond bottom soils. Prog Fish-Cult 55: 210-213

Ban WB, Tian XL, Dong SL, Zhang K and others (2015a) An experimental study on structure optimization for polyculture of Portunus trituberculatus, Litopenaeus vannamei, Ruditapes philippinarum, and Gracilaria lichevoides. Hebei Fish 8:12-18 (in Chinese with English abstract)

Ban WB, Tian XL, Dong SL, Zhang K and others (2015b) Emergy evaluation of four Portunus trituberculatus aquaculture systems. Period Ocean Univ China 46:31-40 (in Chinese with English abstract)

Bayle-Sempere JT, Arreguín-Sánchez F, Sanchez-Jerez P, Salcido-Guevara LA, Fernandez-Jover, D, Zetina-Rejón M J (2013) Trophic structure and energy fluxes around a
Mediterranean fish farm. Ecol Model 248:135-147

* Bradford-Grieve JM, Probert PK, Nodder SD, Thompson D and others (2003) Pilot trophic model for subantarctic water over the Southern Plateau, New Zealand: a low biomass, high transfer efficiency system. J Exp Mar Biol Ecol 289:223-262

Christensen V, Pauly D (1992a) A guide to the Ecopath II software systems (version 2.1), ICLARM software 6. International Center for Living Aquatic Resources Management (ICLARM), Manila

Christensen V, Pauly D (1992b) Ecopath II: a software for balancing steady-state ecosystem models and calculating network characteristics. Ecol Model 61:169-186

Christensen V, Pauly D (eds) (1993) Trophic models of aquatic ecosystems. Working Papers 8432. The World Fish Center, Manila

Christensen V, Walters CJ (2004) Ecopath with Ecosim: methods, capabilities and limitations. Ecol Model 172: 109-139

Christensen V, Walters CJ, Pauly D (2000) Ecopath with Ecosim, Version 5, Help System ${ }^{\odot}$. Fisheries Centre, University of British Columbia, Vancouver and ICLARM, Penang

Christensen V, Walters CJ, Pauly D (2005) Ecopath with Ecosim: a User's Guide (Version 5.1). Fisheries Centre, University of British Columbia, Vancouver

Coll M, Bundy A, Shannon LJ (2009) Ecosystem modelling using the Ecopath with Ecosim approach. In: Megrey BA, Moksness E (eds) Computers in fisheries research, 2nd edn. Springer, Dordrecht, p 225-291

Colléter M, Valls A, Guittonb J, Gascuel D, Pauly D, Christensen V (2015) Global overview of the applications of the Ecopath with Ecosim modeling approach using the EcoBase models repository. Ecol Model 302:42-53

* Costa-Pierce BA, Craven DB, Karl DM, Laws EA (1984) Correlation of in situ respiration rates and microbial biomass in prawn (Macrobrachium rosenbergii) ponds. Aquaculture 37:157-168

*Diana JS, Lin CK, Schneeberger PJ (1991) Relationships among nutrient inputs, water nutrient concentrations, primary production, and yield of Oreochromis niloticus in ponds. Aquaculture 92:323-341

Dickie LM (1972) Food chains and fish production. ICNAF Spec Publ 8:201-221

Dong J, Tian XL, Dong SL, Zhang K, Feng J, He RP (2013) Study on nitrogen and phosphorus budget in polyculture system of Litopenaeus vannamei with Portunus trituberculatus. Period Ocean Univ China 43:16-24 (in Chinese with English abstract)

Dong SL (2015) Ecological foundation of integrated aquaculture in China. Science Press, Beijing (in Chinese)

Dong SL, Zhao W (2004) Aquatic ecology for aquaculture. Chinese Agricultural Press, Beijing (in Chinese)

FDAMC (Fisheries Department of Agriculture Ministry of China) (2016) China 603 Fisheries Yearbook. China Agriculture Press, Beijing (in Chinese)

Feng J, Tian XL, Dong SL, Zhang K, Dong J (2015) Studies on the energy budget of different polyculture systems of swimming crab. Period Ocean Univ China 45:9-47 (in Chinese with English abstract)

F Fetahi T, Schagerl M, Mengistou S, Libralato S (2011) Food web structure and trophic interactions of the tropical highland Lake Hayq, Ethiopia. Ecol Model 222:804-813

Finn JT (1976) Measures of ecosystem structure and function derived from analysis of flows. J Theor Biol 56: 
$363-380$

Fu CP, Zheng ZM, Jin ZW, Hao Q, Lu KH (2012) Effects of 'submerged aeration system' on water quality and phytoplankton community structure in Portunus trituberculatus culture ponds. J Mar Sci 30:74-81 (in Chinese with English abstract)

Funtowicz SO, Ravetz JR (1990) Uncertainty and quality in science for policy. Kluwer, Dordrecht

Ghosh SR, Mohanty AN (1981) Observations on the effect of aeration on mineralization of organic nitrogen in fish pond soil. Isr J Aquacult Bamidgeh 33:50-56

Hargrave BT (1972) Aerobic decomposition of sediment and detritus as a function of particle surface area and organic content. Limnol Oceanogr 17:583-586

Heymans JJ, Coll M, Libralato S, Morissette L, Christensen $\mathrm{V}$ (2014) Global patterns in ecological indicators of marine food webs: a modelling approach. PLOS ONE 9: e95845

Heymans JJ, Coll M, Link JS, Mackinson S, Steenbeek J, Walters C, Christensen V (2016) Best practice in Ecopath with Ecosim food-web models for ecosystem-based management. Ecol Model 331:173-184

Hossain MM, Matsuishi T, Arhonditsis G (2010) Elucidation of ecosystem attributes of an oligotrophic lake in Hokkaido, Japan, using Ecopath with Ecosim (EwE). Ecol Model 221:1717-1730

Jin BC (2010) Using stable isotope to evaluate food sources of pond-cultured sea cucumber (Apostichopus japonicus). PhD thesis, Ocean University of China, Qingdao (in Chinese with English abstract)

Li CH, Lin WL (1995) Grazing rate of zooplankton on bacterioplankton in Donghu Wuhan. Acta Ecol Sin 15:142-147 (in Chinese with English abstract)

Li DS, Lu JR (1998) A device of in situ sediment respiration determining apparatus used in pond. J Ocean Univ Qingdao 28:205-209 (in Chinese with English abstract)

Li J, Yang JM, Dou SZ (1995) Study on the ecological growth efficiency of juvenile redlip mullet. Mark Sci 19:68-69 (in Chinese with English abstract)

Lin Q (2012) Studies on the ecosystem energy transfer and function in the typical waters of Yellow and Bohai Sea. $\mathrm{PhD}$ dissertation, Ocean University of China, Qingdao (in Chinese with English abstract).

Lindeman RL (1942) The trophic-dynamic aspect of ecology. Ecology 23:399-418

Link JS (2010) Adding rigor to ecological network models by evaluating a set of pre-balance diagnostics: a plea for PREBAL. Ecol Model 221:1580-1591

Link JS (2016) Corrigendum to 'Adding rigor to ecological network models by evaluating a set of pre-balance diagnostics: a plea for PREBAL' [Ecol Model 221 (2010) 1580-1591]. Ecol Model 337:348-349

Liu GC, Li DS (1999) Metabolism of bacterial carbon in shrimp cultural enclosure ecosystem. Shuichan Xuebao 23:357-362 (in Chinese with English abstract)

Liu QG, Chen Y, Li JL, Chen L (2007) The food web structure and ecosystem properties of a filter-feeding carps dominated deep reservoir ecosystem. Ecol Model 203: 279-289

* Lorenzen K, Struve J, Cowan VJ (1997) Impact of farming intensity and water management on nitrogen dynamics in intensive pond culture: a mathematical model applied to Thai commercial shrimp pond. Aquacult Res 28: 493-508

Mao XX, Jiang XM, Wang CL, Yi XH (2014) Investigation of zooplankton in two polyculture modes as dominant stocking species of the swimming crab Portunus trituberculatus. J Biol 31:38-41 (in Chinese with English abstract)

Moriarty DJ (1986) Bacterial productivity in ponds used for culture of penaeid prawns. Microb Ecol 12:259-269

Morissette L (2007) Complexity, cost and quality of ecosystem models and their impact on resilience: a comparative analysis, with emphasis on marine mammals and the Gulf of St. Lawrence. PhD dissertation, University of British Columbia, Vancouver

Odum EP (1971) Fundamentals of ecology. Saunders, Philadelphia, PA

Odum WE, Heald EJ (1975) The detritus-based food web of an estuarine mangrove community. In: Cronin LE (ed) Estuarine research. Academic Press, New York, NY, p 265-286

* Pauly D, Christensen V, Walters CJ (2000) Ecopath, Ecosim, and Ecospace as tools for evaluating ecosystem impact of fisheries. ICES J Mar Sci 57:697-706

Qi M, Shen YH, Zhu CH, Wu ZH, Huang XH (2010) A primary study on conversion efficiency of Litopenaeus vannamei feed on artificial diets. Fish Modern 37:34-37 (in Chinese with English abstract)

* Ray S (2008) Comparative study of virgin and reclaimed islands of Sundarban mangrove ecosystem through network analysis. Ecol Model 215:207-216

* Rooney N, McCann K, Gellner G, Moore JC (2006) Structural asymmetry and the stability of diverse food webs. Nature 442:265-269

Schwaerter S, Søndergaard M, Bo R, Jensen LM (1988) Respiration in eutrophic lakes: the contribution of bacterioplankton and bacterial growth yield. J Plankton Res 10: 515-531

Kchwinghamer P, Hargrave B, Peer D, Hawkins CM (1986) Partitioning of production and respiration among size groups of organisms in an intertidal benthic community. Mar Ecol Prog Ser 31:131-142

Shi HL, Jin CL, Lin GZ, Lou B, Mao GM (2010) The aquaculture of Portunus trituberculatus in Zhejiang Province. Hebei Fish 7:39-41 (in Chinese with English abstract)

Song HT, Yu CG, Xue LJ, Yao GZ (2006) The East China Sea economic crab. Ocean Press, Beijing, p 83-86 (in Chinese)

* Straile D (1997) Gross growth efficiencies of protozoan and metazoan zooplankton and their dependence on food concentration, predator-prey weight ratio, and taxonomic group. Limnol Oceanogr 42:1375-1385

* Tian X, Li D, Dong S, Yan X, Qi Z, Liu G, Lu J (2001) An experimental study on closed-polyculture of penaeid shrimp with tilapia and constricted tagelus. Aquaculture 202:57-71

Tsuchiya M, Kurihara Y (1979) The feeding habits and food sources of the deposit-feeding polychaete, Neanthes japonica, (Izuka). J Exp Mar Biol Ecol 36:79-89

Ulanowicz RE (1986) Growth and development: ecosystem phenomenology. Springer, New York, NY

Ulanowicz RE (1997) Ecology, the ascendant perspective. Columbia University Press, New York, NY

Ulanowicz RE (2004) Quantitative methods for ecological network analysis. Comput Biol Chem 28:321-339

* Ulanowicz RE, Goerner SJ, Lietaer B, Gomez R (2009) Quantifying sustainability: resilience, efficiency and the return of information theory. Ecol Complex 6:27-36

Wang JQ, Li D, Dong S, Wang K, Tian X (1998) Experimen- 
tal studies on polyculture in closed shrimp ponds. I. Intensive polyculture of Chinese shrimp (Penaeus chinensis) with tilapia hybrids. Aquaculture 163:11-27

Wang J, Jiang ZH, Dong SL (2001) Role of filter-feeding bivalves in proliferation of phytoplankton community. Ying Yong Sheng Tai Xue Bao 12:765-768

Wang SH, Zhang ZN (1998) Study of Neanthes japonica feeding on natural sediment. J Ocean Univ Qingdao 28: 587-592 (in Chinese with English abstract)

Wetzel RG (1983) Limnology, 2nd edn. Saunders College Publications, Philadelphia, PA

Williams PJLB (1981) Microbial contribution to overall marine plankton metabolism: direct measurements of respiration. Oceanol Acta 4:359-364

Winberg GG (1956) Rate of metabolism and food requirements of fishes. Belorussian State University, Minsk. Fisheries Research Board of Canada Translation Series 194 (1960). Biological Station, Nanaimo, BC

Xu GZ, Zhen CW, Tang TD, Li WJ and others (1987) Barracuda culture. Chinese Agricultural Press, Beijing (in Chinese)

Xu SN, Chen ZZ, Li SY, He PM (2011) Modeling trophic structure and energy flows in a coastal artificial ecosystem using mass-balance Ecopath model. Estuaries Coasts 34:351-363

Yang H, Ma S, Su YP (2010) Differences of food consumption, metabolism and growth of the crab (Portunus trituberculatus) fed fresh, frozen and oven-dried clam (Ruditapes philippinarum) meat. Period Ocean Univ China 40: 65-70 (in Chinese with English abstract)

Yang JM (2001) A study on food and trophic levels of Bohai Sea invertebrates. Mod Fish Inf 16:8-16 (in Chinese with English abstract)

Zhang DX, Zhang K, Tian XL, Dong SL and others (2016) A study on the organic carbon storage of different polyculture systems of Portunus trituberculatus. Haiyang Huzhao Tongbao 2:72-83 (in Chinese with English abstract)

Zhang GF, Yan XW (2010) Clam aquaculture study. Science Press, Beijing (in Chinese)

Editorial responsibility: Adam Hughes, Oban, UK; Marianne Holmer, Odense, Denmark
Zhang HQ, Chu H, Wen D, Zhang DM (2008) Investigation of morphological diversity of heterotrophic bacteria from water column of Portunus trituperculatus [sic] rearing pond. J Liaoning Normal Univ 31:221-224 (in Chinese with English abstract)

Zhang JH, Feng JX, Sun S, He Y, Zhang F (2005) Clearance rate, ingestion rate and absorption efficiency of cultivated clam Ruditapes philippinarum in Jiaozhou Bay, China. Oceanol Limnol Sin 36:548-555 (in Chinese with English abstract)

Zhang K, Tian XL, Dong SL, Dong J, Feng J, He RP, Yan FJ (2015a) Nitrogen and phosphorus budgets of polyculture system of Portunus trituberculatus, Litopenaeus vannamei and Ruditapes philippinarum. Period Ocean Univ China 45:44-53 (in Chinese with English abstract)

Zhang K, Tian XL, Dong SL, Yan FJ, Yang G, Liu RJ, Feng J (2015b) Variation of functional diversity of microbial communities in water of polyculture of Portunus trituberculatus, Litopenaeus vannamei and Ruditapes philippinarum. Isr J Aquacult Bamidgeh 67:1-12

Zhang K, Tian XL, Dong SL, Feng J, He RP (2016) An experimental study on the budget of organic carbon in polyculture ecosystems of swimming crab with white shrimp and short-necked clam. Aquaculture 451:58-64

Zhou B (2015) Research on grass carp (Ctenopharyngodon idella) integrated aquaculture pond ecosystem: based on EwE model. PhD dissertation, Ocean University of China, Qingdao (in Chinese with English abstract)

Zhou B, Dong SL, Wang F (2016) Modeling analysis of the structure of grass carp-silver carp-common polycultured pond ecosystem. Period Ocean Univ China 46:28-36 (in Chinese with English abstract)

Zhou YB, Xie ZH (1995) Secondary production of Neanthe japonica in shrimp ponds. Shuichan Xuebao 19:140-150 (in Chinese with English abstract)

Zhou YG, Ma S, Su YP, Yan BL, Wang XQ, Liu YK (2010) Studies on the effects of polyculture of Litopenaeus vannamei with Portunus trituberculatus. Period Ocean Univ China 40:11-16 (in Chinese with English abstract)

Submitted: February 7, 2017; Accepted: October 4, 2017 Proofs received from author(s): November 21, 2017 